\title{
A COST-BENEFIT ANALYSIS OF PRECONDITIONS AND PREDICTED EFFECTS FROM E-VOTING IMPLEMENTATION IN UKRAINE
}

\author{
Yana M. Sadykova ${ }^{1}$, Mykola V. Starynskyi ${ }^{2}$, Nataliia O. Horobetc ${ }^{1}$, \\ and Yurii M. Zhornokui ${ }^{1}$ \\ ${ }^{1}$ Kharkiv National University of Internal Affairs, ${ }^{2}$ Sumy State University
}

\begin{abstract}
The issue of implementing information technology in the electoral process remains a subject of discussion also in Ukraine. There is no clear position regarding the introduction of e-voting as an element of e-democracy. The analysis of the existing practice of introducing e-voting systems and identifying the possible effects can be the means for making decisions. For this analysis a parametric approach was chosen. Such an analysis is carried out on the basis of Estonia's data, which already introduced an e-voting system with an appropriate extrapolation of the received data concerning Ukraine. The predicted effects of implementing e-voting in Ukraine can be defined in increasing normative electoral load on the polling divisions while the actual electoral load is reduced and the level of trust and access to elections increases. The changes of the active participation of the population in political processes due e-voting introduction are not possible to evaluate at present.
\end{abstract}

Keywords: e-voting, cost-benefit analysis, advantages and disadvantages of e-voting, democratization, e-voting preconditions.

DOI: https://doi.org/10.3176/tr.2018.3.03

\section{Introduction}

The rapid development of information technology has led to the fact that virtually all types of legal relationships emerged or were implemented partly in the e-format. Online services and e-resources have become an integral part of the life of modern society. Reforms that are currently taking place in Ukraine and elsewhere in the world are, in many cases, aimed at ensuring that the relevant areas take into account and utilize the current advances in science and technology, as well as the needs of modern society in terms of mobility, enable access to 
remote resources and services, and more information. Without the effective use of IT potential, as well as the proper distribution of human resources in public services, increasing the level of digital participation in political processes, it is impossible to address the main socio-economic and political problems.

To date, there are several indexes in the world that aim to assess the degree of socio-political transformations and their relevance to democratic ideals in numerical terms: the Economist Intelligence Unit's Democracy Index. The structural components for calculating the index are data in four areas, one of which is political. The political review consists of analyzing the following parameters: overview of the political system for Ukraine; assessment of political stability and strength of the opposition; election watch: information on the latest polls and possible outcomes of the election; policy priorities for the current government; analysis of international relations for the country, and its current foreign policy; our ratings for political and institutional effectiveness in the country. Today, the Ukrainian index is 5.69 (in 2008-6.94, in $2014-5.42$ ).

Another of the transformation indexes is the Bertelsmann Foundation Index. The project analyzes the development and transformation processes towards democracy and market economy in international comparison. The Transformation Index, the BTI, is a global study that combines qualitative, in-depth country assessments with quantitative scores for the performance of 129 countries in transition. The international dialogue on strategies of transformation and leadership in change processes complements the analytical part of the project. The BTI 2018 Country Report states that, while the OSCE and other international and domestic observers recognized that the elections were "competitive, well organized overall and the campaign generally showed respect for the democratic process," they also noted the complexity of the legal framework, lack of confidence in the election administration and the dominance of powerful economic groups over the electoral process as big problems. In the BTI 2018 Country Report (this report covers the period from February 1, 2015 to January 31, 2017) Ukrainian score is 6.9 and place is 36 .

As the research shows, the main factor that determines the rating of sociopolitical transformations according to the BTI is the degree of development of democracy in its various aspects (political participation, the absence of antidemocratic veto-vectors, the functioning of democratic institutions, the adoption of these institutions, the division of branches of power etc). This factor explains almost $70 \%$ of the index (Yakovlev 2010).

Ukraine has a very low level of confidence in the elections, which explains the low level of election turnout. The Central Election Commission (CEC) also identified a number of factors that have an impact on voter confidence in the electoral process. Among all, it was indicated that the more time passes from the time of the end of the voting to the announcement of the results of the vote count, the lower the level of public confidence in the elections as a whole. Regarding the dynamics of the receipt of protocols for the latest electoral processes, only on the fifth to seventh day after the election day, the CEC can offer both Ukrainian 
society and the international community a report on the results of processing protocols of all 100 percent of polling stations (Okhendovsky 2017).

In 2019 elections will take place in Ukraine. There are already practices of using e-voting in countries around the world. Taking into account the aforementioned and the European integration steps of Ukraine, the study of possible socio-economic effects of the introduction of e-voting is relevant.

Keeping this in view, the prime objective of this study is to assess the socioeconomic effects after the implementation of e-voting in Estonia and to define the most predicted changes after implementation e-voting (Internet-voting) in Ukraine.

\section{Literature review}

The researches of the forms, methods, and implications of the introduction of evoting have taken place for a long time. Norris (2005) analyzed the pilot program that took place in 2003 in the UK. Various forms of voting (Internet voting, postal voting and traditional voting forms) and their effectiveness for increasing of turnout were studied. The study shows that in general, the program leads to an increase of the turnout by 15 percent and the effect of postal voting is greater than that of Internet voting.

Most studies are based on data from Estonia, where e-voting has been implemented since 2005. Boshler (2010) and Vassil and Weber (2011) conducted a survey of election data in Estonia in 2007. Boshler (2010) finds that the vote would no longer be a vote for the vote, but it would not reduce the unequal participation of the voters, but it could help the electors who live far from the polling station to participate in the election. Somewhat similar conclusions came from Vassil and Weber (2011).

The issue of advantages and disadvantages of e-voting is constantly raised. In January 2017, Nicole Goodman states that the benefits of e-voting are linked to voter convenience and accessibility, the possibility of increasing voter turnout, decreasing the number of ballots and spoiled election ballots, possible improvements in the effectiveness of the election (Goodman 2017). In addition, the transfer of transactions between a person and a state into an electronic format allows saving significant time, material and human resources and redirecting them from the public to the private sphere (Brintsev 2016).

Moreover, analyzing the stages of the electoral process in Ukraine and the level of automation of election procedures, it was determined that such stages of the election process as the formation of election commissions, the nomination and registration of candidates to the people's deputies of Ukraine, election campaigning, in particular as regards the control of sources of formation and use election funds, counting the votes of voters and setting the results of voting, establishing the results of the elections of people's deputies of Ukraine is already largely automated (Brizko, Tsimbalyuk, and others 2006). The conclusion was drawn that there is objective necessity of full-scale introduction of automated information 
systems in the technological processes of preparation and conduct of elections and referendums in Ukraine irrespective of their types. It will allow to process and transmit huge masses of information on considerable distances in the required format.

Theoretical and practical issues of the creation of legal, organizational and technical principles for the construction, implementation and use of modern automated information and communication and information-analytical systems and technologies in the practice of organizing and conducting elections in Ukraine were investigated by V. M. Furashev and D. A. Lande (2011).

The issue of implementing information technology in the electoral process remains a subject of discussion. In the spring of 2017, an international conference "Using the Newest Information Technologies in the Election Process: Challenges, Risks, Prospects" was held in Kyiv, organized by the Central Election Commission jointly with the Office of the Council of Europe in Ukraine, the International Foundation for Election Systems in Ukraine (IFES) and the OSCE Project Coordinator in Ukraine.

Thus, on the one hand, there is no clear position regarding the introduction of e-voting as an element of e-democracy. The points of view range between two fundamentally opposite points: from the categorical rejection of e-voting (due to the fact that such procedures cannot ensure the integrity of the vote) to the idealizing of e-voting. The analysis of the existing practice of introducing e-voting systems and identifying the possible effects can be the means for making decision.

\section{Methods}

For the socio-economical analysis of the consequences of implementing the electronic voting system, a parametric approach was chosen. Such an analysis is carried out on the basis of Estonia's data, which already introduced an electronic voting system with an appropriate extrapolation of the received data concerning Ukraine.

This research applies a difference-in-difference model to capture a potential effect of internet voting on voter turnout. The effect of internet voting on voter turnout is observed by comparing treatment intensity in the period before the introduction of internet voting to the period after. The period before the first election using internet voting is compared to the period after, and the difference in treatment intensity between the Estonian counties are compared to each other.

Elections of the President, elections to the Verkhovna Rada and local elections are held in Ukraine. The purpose of this research the analysis was made on data on the presidential elections and parliamentary elections in Ukraine. Since the proclamation of Ukraine's independence, the presidential elections in Ukraine (regular and extraordinary) took place in 1991, 1994, 1999, 2004, 2010 and 2014; parliamentary elections (regular and extraordinary) were held in 1994, 1998, 2002, 2006, 2007, 2012, 2014. Data on the elections in Ukraine are taken from 2004 to 
2014 , with the aim of analyzing electoral processes at the present time. Election data up to 2004 do not carry an informative load for the purposes of this study; therefore they have not been taken into account.

Difference-in-difference model requested the data of electoral processes in Estonia between 1993 and 2015. In research there was used the open statistics with access through the Internet. The difference-in-difference model was applied to figure out changes in the election load. For this purpose the methods of juridical statistics were also used.

\section{Results}

Estonia has had democratic elections for over two decades now. In 2005 Estonia became the first country in the world to have nation-wide local elections where people could cast binding votes over the internet. This has given us enough time to draw a number of conclusions.

The main research positions are as follows. Vector of management goals is a description of the ideal mode of operation of the object. The vector of management goals is constructed as a hierarchically ordered set of private management goals that should be implemented in the case of perfect management.

The current state vector of control parameters describes the real state of the object by the parameters included in the vector of goals.

Each of these two vectors is ordered by a multitude of information modules that describe certain parameters of the object, which correspond to the private management objectives. The ordering of information modules in the state vector matches the hierarchy of the vector of goals.

Vector of a management error represents a 'difference' between the vector of goals and the state vector. This vector is the basis for the formation of an assessment of the quality of management by the subject-manager. The assessment of the quality of management is not an independent category, since based on the same vector of the error, it is possible to build a multitude of quality control assessments that are not always interchangeable.

Thus, when considering the issue of implementing e-voting as a management process at the stage of choosing a behavioral option, two sets of information are needed: the vector of the management goals and the current state vector of the control parameters.

The control parameters will be determined on the basic expectations of evoting system implementation. Expectations will be generated based on the expert estimation method.

The main contextual, institutional and historical background of Estonian internet voting were defined in order to understand the key preconditions that led to the successful implementation of internet voting: high technology adoption, high level of everyday Internet usage, wide rate of internet banking, wide mobile penetration, Free Wi-Fi Access points, electronic identity (Solvak and Vassil 
2016). The legal framework is designed to work seamlessly with the technological solutions of e-government.

The availability of voting in the light of the possibility of introducing e-voting is a topical issue for the people of the countryside. The data of research conducted on instructions from the Internet Association of Ukraine by Factum Group Ukraine throughout the territory of Ukraine, excluding Crimea, as at March 2016 compared to September 2015, the influence of the Internet increased to 7\% (or $4 \%$ in absolute terms) - from $58 \%$ to $62 \%$. Almost half of the villagers already have access to the Internet. As well as in large cities, Ukraine has already approached the average European standards (Minchenko 2016).

The dynamism of Internet usage and the formation of a national online audience is steadily positive in Ukraine. Despite the fact that in the world rankings Ukraine now has medium or low average indicators of the information society development, its online audience is quite large $(37.1 \%$ - according to the National Commission for State Regulation of Communications and Informatization of Ukraine and $63.1 \%$ - according to Factum Group Ukraine), modern dynamic and diversified, with significant potential for further development. In general, the main trend of recent years remains, namely, the Ukrainian online audience, due to its qualitative characteristics, itis getting closer to the audiences of the most developed countries of the world (Paniotto, Paulins, and Dubinsky 2016).

However, Speedtest (Global Index), which analyzes the speed of mobile and fixed broadband Internet all over the world, has determined that as at 2017 the speed of mobile Internet in Ukraine below the rating - in 109th place among 122 countries presented in the rating. The average speed of the Ukrainian mobile Internet is 8.46 megabytes per second while downloading, and 2.39 Mbps while uploading. The better situation is with the broadband Internet. In this position Ukraine occupies 39th place with 34.2Mbps and 33.64 Mbps (Dmitrenko 2017). Such data suggests that the e-voting system may not just be loaded in certain regions.

Availability of Internet access, the quality of the digital divide as an indicator before the introduction of e-voting, put the following requirement on the demand: if remote e-voting channels are not generally available, they should be only additional and additional means of voting.

An efficiency indicator can be used to analyze the effectiveness of management activities during the election. This issue is concerned with how resources can be effectively governed within election system: Ef - effectiveness of management

$$
\mathrm{Ef}=\frac{\mathrm{R}}{\mathrm{C}},
$$

where $\mathrm{R}$ - results of function governed system, $\mathrm{C}$ - the total cost calculations of election. In this case $\mathrm{R}=\Delta \mathrm{B}$ (benefits)

Admissible (efficient) introduction e-voting is defined by the ratio:

$$
\text { Ef } \leq \text { Ef }_{\text {e-voting }} \text {. }
$$


The implementation of e-voting system should be evaluated from the point of effectiveness of capital investments. An indicator of the effectiveness of capital investments (Ef invest) in the e-voting development and implementation is the payback period of capital investments, which can be defined:

$$
\mathrm{Ef}_{\text {invest }}=\frac{\mathrm{V}_{\text {invest }}}{\Delta \mathrm{B}}
$$

where $\mathrm{V}_{\text {invest }}$ - volume of capital investments, $\Delta \mathrm{B}$ - change of indicators of the current state (benefits) per year.

Applying the difference-in-deference model and the comparing method some estimation of the effectiveness of capital investments can be made also. For using the diference-in-diference model it were designed Table 2.

Analyzing the static data at elections in Estonia applying diference-in-diference model, it should be concluded that e-voting has increased since the year of its introduction from $1.9 \%$ to $30.5 \%$. In general, data do not indicate an increase in the voters' activity, but a slightly different economic effect is seen in the form of a reduction in polling stations costs.

Okoro (2016) stated that there is a tremendous long-term cost-savings in poll staff time and energy. Indeed, electoral load is one of the indicators that should be taken into account by electoral management. Normative electoral load depends on the number of voters and polling stations.

$$
\text { E load } n=\frac{\text { Voters eligible }}{\text { Polling Divins }} \text {. }
$$

The electoral load on polling stations since e-voting introduction in Estonia has changed in the direction of its increase. However, this does not lead to voting obstacles, since the actual electoral load has changed at the same time.

The actual electoral load in the case of e-voting correlates with the actual turnout and the percentage of I-voters among participating voters.

$$
\text { E load } a=\frac{\text { Participating voters }-I-\text { voters among participating voters }}{\text { Polling divisions }} \text {. }
$$

Index of the load (I load) shows the general trend in the dynamic of election load.

$$
\text { Iload }=\frac{\text { Eload }_{n}}{\text { Eload }_{f}}
$$

In Ukraine elections are conducted by voter turnout at polling stations. where they have to fill out election ballots. One of the remarks about the elections in Ukraine in 2014 was the excessive electoral load on polling stations. Although this was due to the fact that several types of elections were held at the same time. this affected the quality of the election.

One of the e-voting benefits is the voting rights facilitation. Okoro (2016) explains that the electronic capability improves democratic engagement by creat- 
ing an effective platform for informing and engaging citizens in the political process. In the same time Macintosh (2006) states that a valid election is one in which citizens participated freely and fairly to vote and select their representatives. E-voting system provides the much needed freedom, convenience and confidence to vote. However is this relevant in particular for Ukraine and which parameters can be used to assess such advantage?

The world community focuses on the current migration processes that have embraced most of the world's nations today. According to the representative office of the International Organization for Migration in Ukraine, the number of Ukrainians living in the EU territory is constantly growing. According to Eurostat, the number of valid residence permits in the territory of the European Union and the acquisition of citizenship by Ukrainian citizens increased from 666077 in 2008 to 1113659 people in 2016, which is almost 2 times higher. The number of Ukrainians living in Poland increased (from 22 thousand in 2008 to 409 thousand in 2016) (data from ec.europa.eu). Given the data at the end of 2017 in Ukraine, 35850126 voters (data are taken from www.drv.gov.ua) from $2 \%$ to $3 \%$ of voters are abroad in the EU states during the elections. Such a figure is high on its own, but it is still necessary to take into account the fact that the figure of permanent residents who live in foreign countries is not final data and therefore the percentage of voters who will be abroad at the time of the elections is much higher.

Particular attention deserves the potential of the Internet to intensify the sociopolitical and in particular electoral participation of young generations of Ukrainians, which now has a predominantly negative dynamics. Thus, according to the calculations carried out on the results of conducting exit polls, the level of participation of young people aged 18 to 29 years was: during the parliamentary elections of $1998-67 \%$; the first round of the presidential election in $1999-61 \%$; parliamentary elections $2002-59 \%$; the second round of the 2004 presidential election - 71\%; parliamentary elections in 2006 - 57\%; presidential elections 2010 $-57 \%$; parliamentary elections in $2012-47 \%$. In general, during all elections, the level of electoral activity of young people remained below the average level of electoral activity of the population as a whole (Volosevich, Gerasimchuk, and Kostyuchenko 2015).

At the same time, $82 \%$ of respondents from Ukrainian youth have personal Internet access (at home or at work). $77 \%$ have personal computers or laptops, and $59 \%$ have mobile phones and $46 \%$ have smartphones. Most young Internet users use $86 \%$ of the Internet at least one or several times a day (Volosevich, Gerasimchuk, and Kostyuchenko 2015).

\section{Discussion}

Effective. efficient and credible electoral system (e-voting system) can lead to democratization inside Ukraine (D). 


$$
\mathrm{Ef}=\frac{\mathrm{R}}{\mathrm{C}}=\frac{\Delta \mathrm{E} \text { load }+\Delta \mathrm{V} \text { access }+\Delta \mathrm{C} \text { ballot paper }+\Delta \mathrm{P} \text { awareness }+\Delta \mathrm{D}}{\text { direct costs }} .
$$

Table 1 shows the few preconditions of e-voting implementation in Ukraine in comparison with Estonia. The main problem issue is verification.

The calculations based on data of the Estonian National Electoral Committee shows a tendency for changes in the electoral load in Estonia from 1993 to 2015 (Figure 1). The average normative electoral load at the polling station 1993-2002 (before e-voting introduction) is $1108 ; 2005-2015$ it was 1590 . The average actual electoral load 1993-2002 was 735; in 2005-2015 it was 707. The trend is with a slight increase in the average normative electoral load. There is a decrease in the values of the actual electoral load. The dependence of the impact of e-voting introduction on actual election load in Estonia are not statistically significant.

Thus, it is possible to reduce the cost of creating additional polling stations without increasing the actual load or even reducing it.

Based on the data presented in Table 2, the average normative electoral load at the polling station in 2006-2014 was 1079. The average actual electoral load is 662 .

Thus a study conducted showed that there is no trend of decrease of polling station amount in Ukraine. At the same time one of the predictable economical effects from the e-voting introduction is the reduction of actual election load.

The next predictable benefit of e-voting is the change in voting accessibility (V access). Because of the high level of the voters who live (or work) abroad the e-voting system could ensure easier access to voting without the necessity of going back to Ukraine. The immigrant situation in Ukraine leads to the outcome that e-voting is critically important to democracy in Ukraine.

The next assumed benefits are the reduction in costs for the production, distribution and management papers ( $\mathrm{C}$ ballot paper) and increasing the level of public awareness (P awareness). But based on the data of sociological research in 2014 about the most relevant sources of information on events of social and political life in Ukraine, the most popular information sources are national television channels $-89.3 \%$ of respondents and $60.2 \%$ of who consider it as the main way of obtaining information. Internet is not considered as the main means of information, only $17.7 \%$ of respondents mostly use the network. The reasons for this attitude lie in the specifics of this source. Internet is very popular among young people (Balakireva, Sereda, and Dmitruk 2015).

At the end of 2006 there was a change in the paradigm of society from a traditional post-informational state. A high level of correlation between age groups of the Ukrainian population and the specific gravity of the population by the age groups from 18 to 45 who are a daily user of the Internet is revealed (based on materials of State Statistics Service of Ukraine). It means that from the additional informational source the Internet technologies actually become one of the main channels for obtaining political information. The study indicates an acceleration of the replacing traditional voting technologies dynamics with modern information Internet technologies. 
Table 1. Estonian statistical overview 1993-2015

\begin{tabular}{|c|c|c|c|c|c|c|c|c|c|c|c|c|}
\hline & 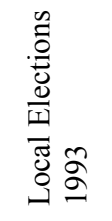 & 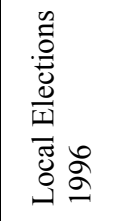 & 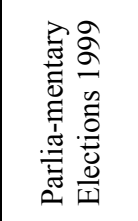 & 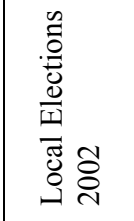 & 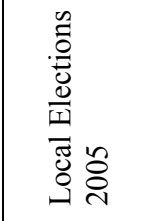 & 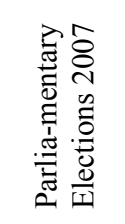 & 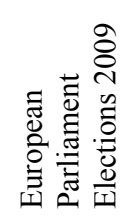 & 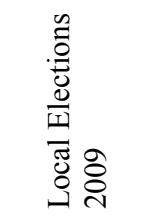 & 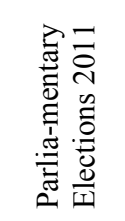 & 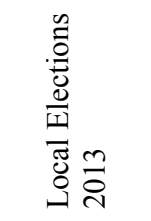 & 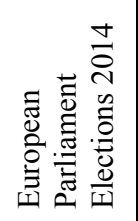 & 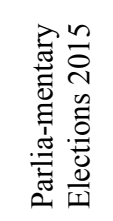 \\
\hline Eligible voters & 880296 & 879034 & 1052404 & 1021439 & 1059292 & 897243 & 909628 & 1094317 & 913346 & 1086935 & 902873 & 899793 \\
\hline
\end{tabular}

voters (voters

turned out)

Voter turnout $\%$

I-voters

I-votes counted

I-votes cancelled

(replaced with

paper ballot)

I-voters among

eligible voters

I-voters among

participating

voters

I-votes among

advance votes

I-votes cast

abroad among

I-votes (based on

$\begin{array}{lllll}52.6 & 52.5 & 49.8 & 52.5 & 47.4\end{array}$

47.4

61.9

$43.9 \quad 60.6$

63.5

58.0

36.5

64.2

$\begin{array}{llll}- & - & - & -\end{array}$

9287

30275

58669

104413

140846

133808

$151 \quad 176491$

32

55

100

82

146

46

162

IP-address)*

$\begin{array}{cccccccc}0.9 \% & 3.4 \% & 6.5 \% & 9.5 \% & 15.4 \% & 12.3 \% & 11.4 \% & 19.6 \% \\ 1.9 \% & 5.5 \% & 14.7 \% & 15.8 \% & 24.3 \% & \mathbf{2 1 . 2 \%} & \mathbf{3 1 . 3 \%} & \mathbf{3 0 . 5 \%} \\ & & & & & & & \\ 7.2 \% & 17.6 \% & 45.4 \% & 44 \% & 56.4 \% & 50.5 \% & 59.2 \% & 59.6 \% \\ \text { n.a. } & 2 \% & 3 \% & 2.8 \% & 3.9 \% & 4.2 \% & 4.69 \% & 5.71 \% \\ & 51 \text { states } & 66 \text { states } & 82 \text { states } & 105 \text { states } & 105 \text { states } & 98 \text { states } & 116 \\ & & & & & & & \end{array}$




\begin{tabular}{|c|c|c|c|c|c|c|c|c|c|c|c|c|}
\hline & 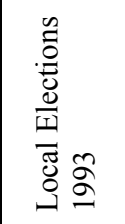 & 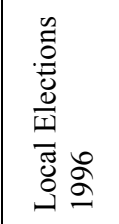 & 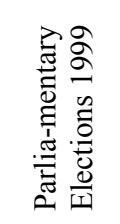 & 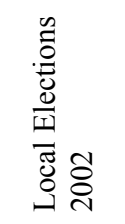 & 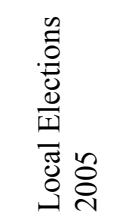 & 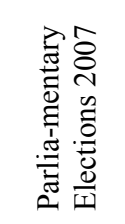 & 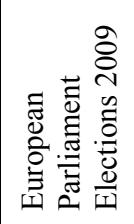 & 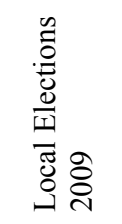 & 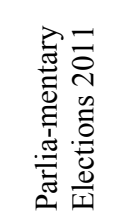 & 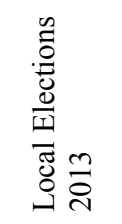 & 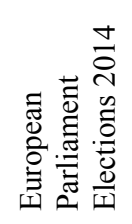 & 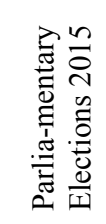 \\
\hline $\begin{array}{l}\text { Valid ballot } \\
\text { papers }\end{array}$ & 454720 & 456882 & 518582 & 529596 & 496336 & 550213 & 396982 & 658213 & 575133 & 625336 & 328493 & 574153 \\
\hline $\begin{array}{l}\text { Invalid ballot } \\
\text { papers }\end{array}$ & 8723 & 4771 & 5860 & 6448 & 6168 & - & 2199 & 4600 & 5131 & 4714 & 1273 & 3757 \\
\hline $\begin{array}{l}\text { Percentage of } \\
\text { invalid ballot } \\
\text { papers }(\%)\end{array}$ & 1.99 & 1.0 & 1.1 & 1.2 & 1.2 & 0 & 0.6 & 0.7 & 0.9 & 0.7 & 0.4 & 0.7 \\
\hline Polling divisions & 706 & 678 & 668 & 656 & 660 & 657 & 627 & 632 & 625 & 582 & 566 & 547 \\
\hline
\end{tabular}




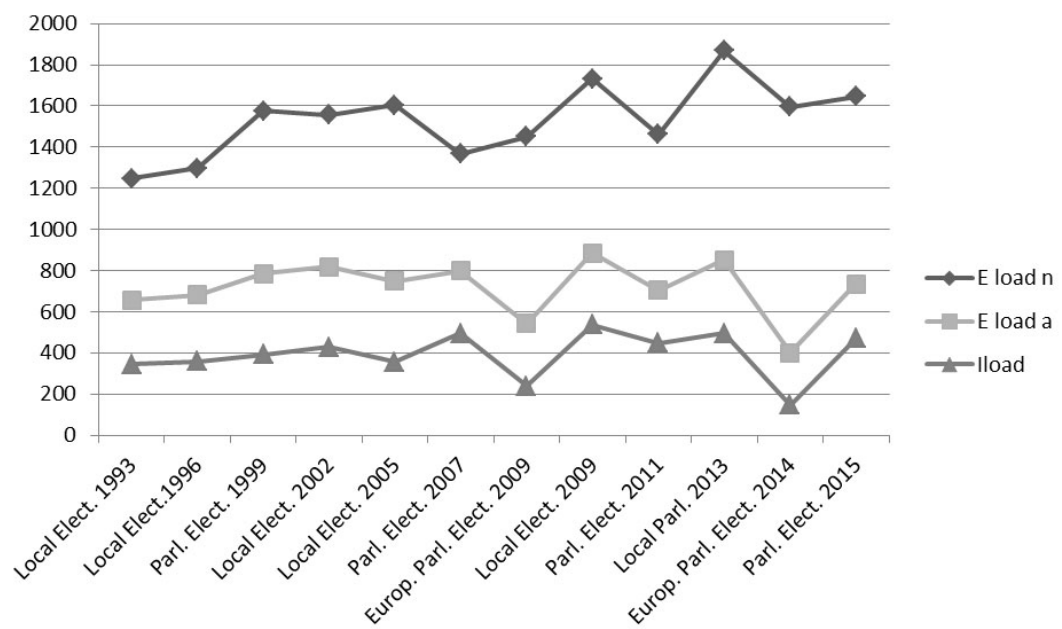

Figure 1. Dynamics of election load in Estonia 1993-2015. Source: Complied and calculated by authors based on https://www.google.com/url? sa=t\&rct=j\&q=\&esrc=s\&source=web\&cd=1\&cad= rja\&uact $=8 \&$ ved $=2$ ahUKEwjj4vfZzIfbAhVLECwKHZ6pD8UQFjAAegQIABAr\&url=http $\% 3 \mathrm{~A} \% 2$ F\%2Fwww.vvk.ee\%2F\%3Flang\%3Den\&usg=AOvVaw1d6_Nf5jewYd2EKjtGX6AzEstonian

Table 2. Ukrainian statistical overview 2004-2014

\begin{tabular}{|c|c|c|c|c|c|c|c|}
\hline & $\begin{array}{c}\text { Parlia- } \\
\text { mentary } \\
\text { Elections } \\
2006\end{array}$ & $\begin{array}{c}\text { Parlia- } \\
\text { mentary } \\
\text { Elections } \\
2007\end{array}$ & $\begin{array}{c}\text { President } \\
\text { Elections } \\
2010 \\
\text { I step }\end{array}$ & $\begin{array}{c}\text { President } \\
\text { Elections } \\
2010 \\
\text { II step }\end{array}$ & $\begin{array}{c}\text { Parlia- } \\
\text { mentary } \\
\text { Elections } \\
2012\end{array}$ & $\begin{array}{l}\text { President } \\
\text { Elections } \\
2014\end{array}$ & $\begin{array}{c}\text { Parlia- } \\
\text { mentary } \\
\text { Elections } \\
2014\end{array}$ \\
\hline Eligible voters & 37528884 & 37588040 & 36968041 & 37051449 & 36213010 & 34214652 & 30921218 \\
\hline $\begin{array}{l}\text { Participating } \\
\text { voters (voters } \\
\text { turned out) }\end{array}$ & 25360392 & 23315257 & 24588268 & 25493529 & 20797206 & 18019504 & 16052228 \\
\hline Voter turnout \% & 67 & 62.02 & 66.5 & 68.8 & 57.4 & 52.7 & 51.9 \\
\hline $\begin{array}{l}\text { Invalid ballot } \\
\text { papers }\end{array}$ & 490595 & 379658 & 405765 & 305837 & 409068 & 244555 & 298402 \\
\hline $\begin{array}{l}\text { Percentage of } \\
\text { invalid ballot } \\
\text { papers (\%) }\end{array}$ & 1.93 & 1.68 & 1.65 & 1.2 & 1.97 & 1.36 & 1.86 \\
\hline $\begin{array}{l}\text { Polling } \\
\text { divisions }\end{array}$ & 34039 & 33974 & 33559 & 33554 & 33650 & 33646 & 29786 \\
\hline $\begin{array}{l}\text { Members of } \\
\text { polling } \\
\text { divisions }\end{array}$ & 541668 & 491663 & 803105 & 537058 & 498256 & $\begin{array}{l}\text { about } \\
400000\end{array}$ & $\begin{array}{c}\text { More than } \\
471000\end{array}$ \\
\hline
\end{tabular}

Source: Complied and calculated by authors based on Ukrainian National Electoral Committee. 
Analyzing the Vinvest of e-voting implementation the direct costs will be taken as base. The total price includes expenses for hardware $(\mathrm{H})$, software $(\mathrm{S})$, technical support before and on election day (TS), training of election officials, project management and implementation (Training), voter information (Vinformation), independent control of equipment and audit (Control), evaluation (Ev). Cost may be an argument for a simpler voting process.

$$
\Delta \mathrm{B}=\Delta \mathrm{E} \text { load }+\Delta \mathrm{V} \text { access }+\Delta \mathrm{C} \text { ballot paper }+\Delta \mathrm{P} \text { awareness }+\Delta \mathrm{D} .
$$

Formula of effectiveness of capital investments in e-voting system will have following view:

$$
\mathrm{Ef}_{\text {invest }}=\frac{\mathrm{H}+\mathrm{S}+\mathrm{TS}+\text { Training }+\mathrm{V} \text { information }+ \text { Control }+\mathrm{Ev}}{\Delta \mathrm{E} \text { load }+\Delta \mathrm{V} \text { access }+\Delta \mathrm{C} \text { ballot paper }+\Delta \mathrm{P} \text { awareness }+\Delta \mathrm{D}} .
$$

Table 3. Assessment results of the current technical state vector of control parameters before evoting introduction in Ukraine

\begin{tabular}{c|l|c|c|c}
\hline & Control parameters & Estonia (2005) & Ukraine (2016) & $\begin{array}{c}\text { Results of } \\
\text { assessment }\end{array}$ \\
\hline 1. & Technology adoption & High & Low & No \\
2. & $\begin{array}{l}\text { Level of everyday } \\
\text { Internet usage }\end{array}$ & $\begin{array}{c}\text { High } \\
\text { (approximation 63\%) }\end{array}$ & $\begin{array}{c}\text { High } \\
\text { (approximation 52.5\%) }\end{array}$ & Yes \\
3. & $\begin{array}{l}\text { Rate of Internet } \\
\text { banking }\end{array}$ & $\begin{array}{c}\text { Wide } \\
\text { Medium }\end{array}$ & No \\
4. & Mobile penetration & Wide & (approximation 40 $\%)$ & Yes \\
& & (almost 100\%) & Wide & (almost 100\%) \\
5. & Electronic identity & more than 90\% & No & No \\
\hline
\end{tabular}

Source: Complied and calculated by authors based on the materials by Solvak and Vassil 2016. materials of National Commission for State Regulation of Communications and Informatization of Ukraine

\section{Conclusion}

The current trend in Ukraine is a high level of correlation between e-voting and democratization process due to groups of the Ukrainian population. This conclusion was made because the necessity to simplify the access for voting. The predicted effect from implementing e-voting in Ukraine can be defined in increasing normative electoral load on the polling divisions while the actual electoral load is reduced. But the main e-voting challenge is to reach changes in democratization.

The level of the use of Internet technologies is increasing in Ukraine. The percentage of the population using the Internet every day is going to reach the maximum. Thus, it can be argued that Internet governance and e-voting in Ukraine 
have a significant potential. But currently there are no technical preconditions for e-voting introduction (the lack of electronic identity system, the low level of Internet banking, issues of the availability of Internet access and the quality of the digital divide). The implementation of e-voting system without these preconditions will be inefficient.

The increasing of the active participation of the population in political processes due e-voting introduction is not possible at present. It has been confirmed that there is no effect of Internet voting on the voter turnout, even if the use of Internet voting has increased during the time period. Effect on the voter turnout could be forecast after decades after using the e-voting system.

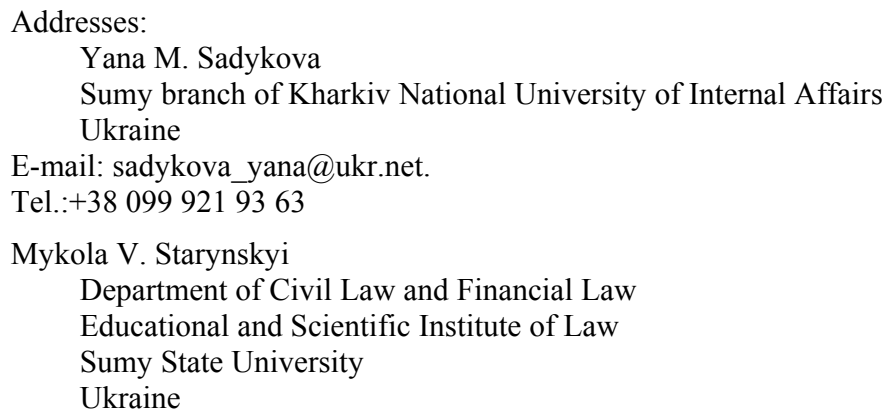

\section{References}

Balakireva, O. M., Yu. V. Sereda, and D. A. Dmitruk (2015) Sociological slices of Ukrainian society (monitoring of socioeconomic expectations of the population: 2005-2014): scientific report. Kiev: National Academy of Sciences of Ukraine; State Enterprise Institute of economy and predicting. National Academy of Sciences of Ukraine.

Bochsler, D. (2010) Can Internet voting increase political participation? Remote electronic voting and turnout in the Estonian 2007 parliamentary elections. Budapest: Centre for the Study of Imperfections in Democracies. Central European University.

Brintsev, O. V. (2016) Electronic court in Ukraine. Experience and perspectives. Harkiv.

Brizko. V., V. Tsimbalyuk, M. Shvets, M. Koval, and Yu. Bazanov (2006) E-future and information law. Kiev: Research Center of Legal Informatics of the Academy of Legal Sciences of Ukraine.

Dmitrenko, O. (s.a.) Ukraine in 109th place on the speed of the mobile Internet-one of the worst indicators in the world. Available online at <http://watcher.com.ua/2017/08/10/ukrayina-na109-mistsi-za-shvydkistyu-mobilnoho-internet-odyn-z-nayhirshyh-pokaznykiv-u-sviti/> . Accessed on April 9, 2018.

Furashev, V. M. and D. A. Lande (2012) Bases of informational and social legal modeling. Kiev: LTD PanTot.

Goodman, N. (2017) Online voting: a path forward for federal elections. Available online at $<$ https://www.canada.ca/en/democratic-institutions/services/reports/online-voting-pathforward-federal-elections.html $>$. Accessed on April 9, 2018.

Macintosh, A. (2006) "E-participation inp-making: the research and the challenges". In P. Cunningham and M. Cunningham, eds. Exploiting the knowledge economy: issues. applications and case study. Amsterdam: IOS Press. 
Minchenko, O. (s.a.) Coverage of the Internet in Ukraine for the first time exceeded $60 \%$ - statistics. Available online at $<\mathrm{http}: / /$ watcher.com.ua/2016/03/28/pronyknennya-internetu-v-ukrayinivpershe-perevyschylo-60>. Accessed on April 9, 2018.

Norris, P. (2005) E-voting as the magic ballot for European Parliamentary elections? Evaluating e-voting in the light of experiments in UK local elections. London: A. H. Trechsel \& F.

Okhendovsky, M. (2017) "The introduction of the latest information technologies in Ukraine can and must become a means of raising the level of public confidence in election results". Bulletin of the Central Election Commission 1, 13-15.

Okoro, E. (2017) "Electronic voting operations and capabilities in sub-Sahara Africa: a cost-benefit analysis". Technology Integration and Transformation of Elections in Africa: An Evolving Modality 332-349.

Paniotto, Vl., Aldis Paulinsh, and I. Dubinsky (s.a.) Infiltration of the Internet in Ukraine. Fourth quarter of 2016 Factum Group Ukraine. Available online at $<\mathrm{http} / /$ inau.ua/sites/default/ files/file/1701/iv_kvartal_2016.pptx>. Accessed on April 9, 2018.

Recommendation CM / Rec (2009) 1 of the Committee of Ministers to member states on electronic democracy (e-democracy) (Adopted by the Committee of Ministers on February 18. 2009 at the 1049th meeting of ministers' deputies). Available online at $<\mathrm{https} / / \mathrm{www} \cdot \mathrm{coe} . \mathrm{int} / \mathrm{t} /$ dgap/democracy/activities/ggis/cahde/2009/RecCM2009_1_and_Accomp_Docs/Recommend ation\%20CM Rec 2009 1E FINAL PDF.pdf $>$. Accessed on April 9, 2018.

Recommendation $C \bar{M} / \operatorname{Rec}(20 \overline{1} 7) \overline{5} 1$ of the Committee of Ministers to member states on e-voting standards. Available online at $<\mathrm{https}: / / \mathrm{rm}$.coe.int/1680726f6f $>$. Accessed on April 9, 2018.

Solvak, M. and K. Vassil (2016) E-voting in Estonia: technological diffusion and other developments over ten years (2005-2015). Tartu: University of Tartu. Johan Skytte Institute of Political Studies.

Vassil, K. and T. Weber (2011) "A bottleneck model of e-voting: why technology fails to boost turnout". New Media \& Society 13, 8, 1336-1354.

Volosevich, I., S. Gerasimchuk, and T. Kostyuchenko (2012) Youth participation in public life: experience, opportunities, barriers. (Annual Report to the President of Ukraine. the Verkhovna Rada of Ukraine. Cabinet of Ministers of Ukraine on the Situation of Youth in Ukraine (in 2011). Ministry of Education and Science. Youth and Sports of Ukraine. State Service for Youth and Sports of Ukraine.) Kiev.

Yakovlev, M. (2010) "Factor analysis of causes of social and political transformation in Bertelsmann transformation index 2010". Scientific Notes 108, 12-16. 
